\title{
Regulation of tumour necrosis factor-alpha release from human adipose tissue in vitro
}

\author{
C P Sewter, J E Digby, F Blows, J Prins and S O'Rahilly \\ Departments of Medicine and Clinical Biochemistry, University of Cambridge, Addenbrooke's Hospital, Hills Road, Cambridge CB2 2QQ, UK \\ (Requests for offprints should be addressed to C P Sewter)
}

\begin{abstract}
Tumour necrosis factor-alpha (TNF- $\alpha$ ), secreted by cells of the macrophage-monocyte lineage, has a well established role in inflammation and host-defence. The more recent discovery that adipocytes also secrete TNF- $\alpha$ has led to a substantial body of research implicating this molecule in the insulin resistance of obesity. However, little is known about the normal regulation of TNF- $\alpha$ release from human adipose tissue. In particular, it is not known whether adipocyte production of TNF- $\alpha$ is responsive to similar or different molecular regulators than those relevant to macrophages. TNF- $\alpha$ release from cultured human adipose tissue and isolated adipocytes was examined using an ELISA. Insulin, cortisol or the thiazolidinedione, BRL 49653, did not have a significant effect on TNF- $\alpha$ release from adipose tissue or isolated adipocytes. In contrast, lipopolysaccaride (LPS), a major stimulus of TNF- $\alpha$ protein production in monocytes and macrophages, resulted in a fivefold stimulation of TNF- $\alpha$ release from human adipose tissue. Significant stimulation of TNF- $\alpha$ release was also seen from isolated adipocytes, indicating that the increase in TNF- $\alpha$ release from adipose
\end{abstract}

tissue in the presence of LPS is unlikely to be entirely attributable to contaminating monocytes or macrophages. Consistent with this observation was the finding that mRNA for CD14, a known cellular receptor for LPS, is expressed in human adipocytes. The increase in TNF- $\alpha$ protein release in response to LPS was blocked by an inhibitor of the matrix metalloproteinase responsible for the cleavage of the membrane-bound proform of TNF- $\alpha$, indicating that this release represented regulated secretion and was not due to cell lysis.

In conclusion, the regulation of TNF- $\alpha$ protein release from human adipose tissue and isolated adipocytes appears to be similar to its regulation in cell types more traditionally implicated in host defence. The production by the adipocyte of a range of molecules involved in host defence - TNF- $\alpha$, factors D, B and C3, interleukin-6, and macrophage colony-stimulating factor - suggest that this cell type may make a significant contribution to innate immunity.

Journal of Endocrinology (1999) 163, 33-38

\section{Introduction}

Tumour necrosis factor-alpha (TNF- $\alpha$ ) is a proinflammatory cytokine secreted by several cell types such as monocytes (Waage \& Bakke 1988), macrophages (Mijatovic et al. 1997) and adipocytes (Hotamisligil et al. 1995). It is produced as a $26 \mathrm{kDa}$ active membrane-bound precursor that is proteolytically cleaved by a matrix metalloproteinase (TNF- $\alpha$ converting enzyme (TACE)) to release a $17 \mathrm{kDa}$ soluble form (Gearing et al. 1994). Its expression and production in macrophages have been shown to be increased on exposure to endotoxins such as lipopolysaccharide (LPS) (Mijatovic et al. 1997), a component of the cell wall of Gram-negative bacteria. TNF- $\alpha$ has an important role as a mediator of the acute phase response and, in addition to an immunological function, it has been shown to have a variety of effects on lipid metabolism and adipocyte function. These include the stimulation of lipolysis through increases in hormone- sensitive lipase expression (Sumida et al. 1997) and inhibition of lipoprotein lipase (Fried \& Zechner 1989), induction of preadipocyte dedifferentiation (decreasing CCAAT/enhancer binding protein (Stephens \& Pekala 1991) and peroxisome proliferator-activated receptor gamma (PPAR $\gamma$ ) (Zhang et al. 1996)), promotion of adipocyte apoptosis (Prins et al. 1997) and induction of insulin resistance (decreasing GLUT4 (Hauner et al. 1995) and insulin-stimulated autophosphorylation of insulin receptor and phosphorylation of insulin receptor substrate-1 (Feinstein et al. 1993)). Expression of TNF- $\alpha$ in adipose tissue has been shown to be increased in rodent and human obesity and to correlate with insulin resistance (Hotamisligil et al. 1995, Kern et al. 1995). As a result of these observations, the paracrine effects of TNF- $\alpha$ released by adipocytes have been proposed to underlie the link between obesity and insulin resistance (Hotamisiligil et al. 1993). Despite the potential pathogenic importance of adipocyte TNF- $\alpha$ in obesity remarkably little is known 
about the normal role of TNF- $\alpha$ in human adipose tissue. We reasoned that a better definition of the molecular regulators of TNF- $\alpha$ in human adipose tissue might provide clues to the function of this cytokine in normal human fat cell biology.

\section{Materials and Methods}

\section{Acquisition of human tissue}

Omental and subcutaneous adipose tissue biopsies (approximately $3 \mathrm{~g}$ ) were obtained from patients undergoing elective open surgery. None of the patients had diabetes or severe systemic illness. Cambridge Local Research Ethics Committee approval was obtained, and all patients gave their informed consent. The tissue donor group consisted of 11 women (ages 49.2 $\pm 15 \cdot 2$ years; body mass index (BMI) $25 \cdot 9 \pm 4 \cdot 3 \mathrm{~kg} / \mathrm{m}^{2}$ ) and five men (ages $71 \cdot 2 \pm 8 \cdot 8$ years; BMI $26 \pm 4 \cdot 5 \mathrm{~kg} / \mathrm{m}^{2}$ ).

\section{Adipose tissue culture}

Whole adipose tissue was separated from surrounding blood vessels, diced finely and washed twice in Hanks' balanced salt solution (HBSS) containing $0 \cdot 2 \%$ BSA. Small pieces of tissue were then placed in sterile tissue culture plates containing pre-equilibrated medium 199 containing $10 \%$ fetal bovine serum, $2 \mathrm{mM} \mathrm{L-glutamine,} 100 \mathrm{U} / \mathrm{ml}$ penicillin, $0.1 \mathrm{mg} / \mathrm{ml}$ streptomycin, $33 \mu \mathrm{M}$ biotin, $17 \mu \mathrm{M}$ pantothenic acid. Different test compounds were also added to the medium: human insulin $(7 \mu \mathrm{M})$, cortisol $(1 \mathrm{mg} / \mathrm{ml})$, LPS $(50 \mu \mathrm{g} / \mathrm{ml})$, a thiazolidinedione BRL $49653\left(10^{-7} \mathrm{M}\right)$ (from SmithKline Beecham Pharmaceuticals, Harlow, Essex, UK), a metalloproteinase inhibitor BB3103 $(10 \mu \mathrm{M})$ (from British Biotechnology, Oxford, UK) and dimethyl sulphoxide. The plates were then incubated under standard conditions $\left(37^{\circ} \mathrm{C} / 5 \%\right.$ $\mathrm{CO}_{2}$ ). After $20 \mathrm{~h}$, medium was collected from each well and frozen at $-80{ }^{\circ} \mathrm{C}$ before measurement of TNF- $\alpha$ protein levels by ELISA. The tissue samples were collected from each well, blotted onto filter paper to remove excess medium, and weighed. TNF- $\alpha$ levels were expressed as pg TNF $\alpha$ per mg adipose tissue per hour and fold increase or decrease relative to the control (medium only). Unless specifically indicated, all reagents were obtained from Sigma Chemical Company, Poole, Dorset, UK.

\section{Adipocyte isolation and culture}

Adipose tissue biopsies were taken under sterile conditions at the time of surgery and placed in normal saline. The transport time to the laboratory was less than $1 \mathrm{~h}$. The tissue was diced finely into $1-2 \mathrm{~mm}$ pieces. All instruments were sterile disposable or autoclaved. The diced tissue was digested in a collagenase solution containing
HBSS, $3 \mathrm{mg} / \mathrm{ml}$ collagenase (type II) and 1.5\% BSA. At least three volumes more digest solution than the volume of tissue was used. The digestion was carried out in a shaking waterbath at $37^{\circ} \mathrm{C}$ for approximately $1 \mathrm{~h}$. After filtration through a $260 \mu \mathrm{m}$ steel mesh, the adipocytes were allowed to float to the surface and collected using a pasteur pipette. After two washes in HBSS, aliquots of adipocytes were dispensed into tissue culture plates containing pre-equilibrated 199 medium and test compounds (see adipose tissue culture). After $20 \mathrm{~h}$, infranatants were harvested from beneath the adipocyte layer and frozen at $-80{ }^{\circ} \mathrm{C}$ before measurement of TNF- $\alpha$ by ELISA. Results are expressed as pg TNF $\alpha$ per $\mu$ ladipocyte suspension per hour or percentage increase or decrease relative to the control (medium alone).

\section{TNF- $a$ protein measurement}

TNF- $\alpha$ levels were determined in culture medium using a commercially available ELISA kit (Genzyme Diagnostics, Cambridge, MA, USA). The manufacturer's procedure for enhanced sensitivity was followed. The assay range was $4-512 \mathrm{pg} / \mathrm{ml}$, with a limit of sensitivity of $500 \mathrm{fg} / \mathrm{ml}$. The intra-assay coefficient of variation was $9 \cdot 67 \%$, and the inter-assay coefficent of variation was $12 \cdot 47 \%$.

\section{Detection of CD14 $m R N A$ by reverse transcription-polymerase chain reaction}

RT-PCR was carried out on RNA extracted from human adipocytes, preadipocytes and monocyte cells. Adipocyte and preadipocyte cells were isolated by collagense digestion of whole adipose tissue as described above. Monocyte cells were isolated from whole blood using HISTOPAQUE-1077 from Sigma. The manufacturer's procedure was followed. RNA was extracted using a guanidium thiocyanate-phenol technique (Tri Reagent, Sigma). RNA samples were treated with RNase inhibitor and DNase and quantified by spectrophotometry. The integrity of RNA samples was assessed by agarose gel electrophoresis and ethidium bromide staining. The reverse transcription reaction was performed in a $20 \mu \mathrm{l}$ volume containing $5 \mathrm{mM} \mathrm{MgCl} 2,1 \times$ reverse transcriptase buffer (Promega, Cambridge, UK), $1 \mathrm{mM}$ dNTPs (Pharmacia Biotech, St Albans, Herts, UK), 10 ng random hexamers (Promega). The reactions were incubated at $65^{\circ} \mathrm{C}$ for $5 \mathrm{~min}$ to remove any residual DNAase A activity and allowed to cool to room temperature. One microlitre Moloney murine leukemia virus reverse transcriptase (Promega) was added to the reactions (except the control) and incubated at $37^{\circ} \mathrm{C}$ for $1 \mathrm{~h}$. The control reaction, containing no reverse transcriptase, allowed for the detection of any possible genomic DNA contamination in the RNA samples after PCR. A further control containing all reagents except RNA was also included to 
allow the detection of any possible DNA/RNA contamination of reagents. PCR was then performed on $200 \mathrm{ng}$ first-strand cDNA in a $50 \mu \mathrm{l}$ volume containing $1 \mathrm{mM} \quad \mathrm{MgCl}_{2}, \quad 0 \cdot 2 \mu \mathrm{M}$ each of CD14 sense (5'GGAAAGAAGCTAAAGCACTT-3') and CD14 antisense (5'-TTTAGAAACGGCTCTAGGTT-3') primers, $0.15 \mathrm{mM}$ dNTPs, $1 \times \mathrm{NH}_{4}$ reaction buffer, 2.5 units Advantage 2 Taq polymerase (Clontech, Palo Alto, CA, USA). Cycling parameters were: $94{ }^{\circ} \mathrm{C}$ for $1 \mathrm{~min}, 50{ }^{\circ} \mathrm{C}$ for $1 \mathrm{~min}, 68^{\circ} \mathrm{C}$ for $1 \mathrm{~min}$ (30 cycles). PCR products were confirmed as CD14 by nucleotide sequencing. All sequencing was carried out using Dideoxy terminator chemistry (Perkin-Elmer, Foster City, CA, USA) and electrophoresed on an ABI 377 automated DNA sequencer.

\section{Statistical analysis}

A paired Wilcoxon non-parametric test was used for statistical analysis. Results are expressed as means \pm s.E.M.

\section{Results}

Mean release of TNF- $\alpha$ from whole adipose tissue and isolated adipocytes in culture medium was $0.068 \pm 0.02 \mathrm{pg} / \mathrm{mg}$ adipose tissue per hour and $0 \cdot 017 \pm 0 \cdot 01 \mathrm{pg} / \mu \mathrm{l}$ adipocyte suspension per hour respectively. Stability of TNF- $\alpha$ protein in the medium was confirmed by spiking medium containing whole adipose tissue with known amounts of TNF- $\alpha$ and quantitating TNF- $\alpha$ protein concentrations after a $20-\mathrm{h}$ incubation relative to an unspiked control (data not shown). There was no correlation between TNF- $\alpha$ protein release and BMI or age and no consistent gender differences were seen.

Exposure to insulin $(7 \mu \mathrm{M})$, cortisol $(1 \mathrm{mg} / \mathrm{ml})$ or BRL $49653\left(10^{-7} \mathrm{M}\right)$ had no significant effect on TNF- $\alpha$ release from either whole adipose tissue (Fig. 1) or isolated adipocytes (Fig. 2). In contrast, exposure to LPS resulted in a mean fivefold ( \pm 1.85 s.E.M.) increase in TNF- $\alpha$ release from adipose tissue after $20 \mathrm{~h}$ (relative to controls) $(P=0 \cdot 0134)$. Figure 3 shows that BB3103 $(10 \mu \mathrm{M})$, a matrix metalloproteinase inhibitor, was able to inhibit LPS-stimulated TNF- $\alpha$ release from adipose tissue over the $20-\mathrm{h}$ period by $90 \pm 3 \cdot 8 \% \quad(P=0 \cdot 002) . \quad \mathrm{BB} 3103$ $(10 \mu \mathrm{M})$ inhibited basal (unstimulated) TNF- $\alpha$ release from adipose tissue by $30 \pm 17 \cdot 4 \%(P=\mathrm{NS})$. The inhibitory effect of $\mathrm{BB} 3103$ suggests that the increase in release of TNF- $\alpha$ from adipose tissue exposed to LPS is due to a bona fide effect of LPS and not due to cell lysis. LPS also had a stimulatory effect on TNF- $\alpha$ release from isolated adipocytes (Fig. 2), although to a lesser extent compared with whole adipose tissue $(1.5 \pm 0 \cdot 15$-fold relative to

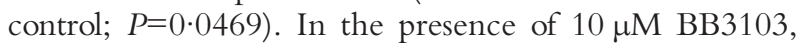
this increase was inhibited by $70 \pm 13 \cdot 75 \% \quad(P=0 \cdot 03)$

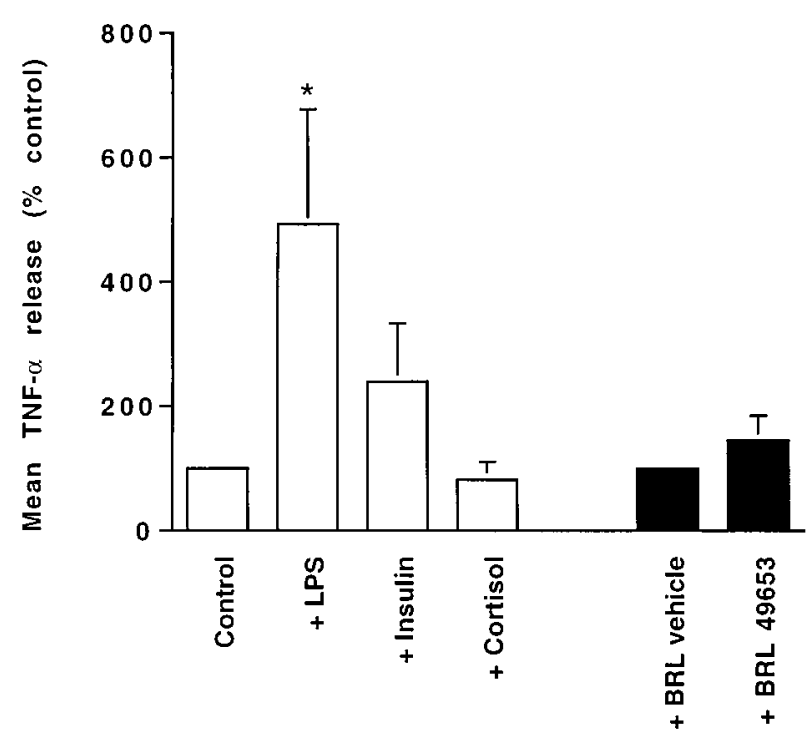

Figure 1 TNF- $\alpha$ release into the incubation medium from human adipose tissue after a 20-h incubation period in medium alone (Control) or medium containing $50 \mu \mathrm{g} / \mathrm{ml}$ LPS $(n=14), 7 \mu \mathrm{M}$ insulin $(n=11), 1 \mathrm{mg} / \mathrm{ml}$ cortisol $(n=11)$, or $10^{-7} \mathrm{M}$ BRL 49653 ( $\left.n=11\right)$. In each experiment, samples were incubated in duplicate. Data are expressed as means \pm S.E.M. ${ }^{*} P=0.0314$ compared with Control.

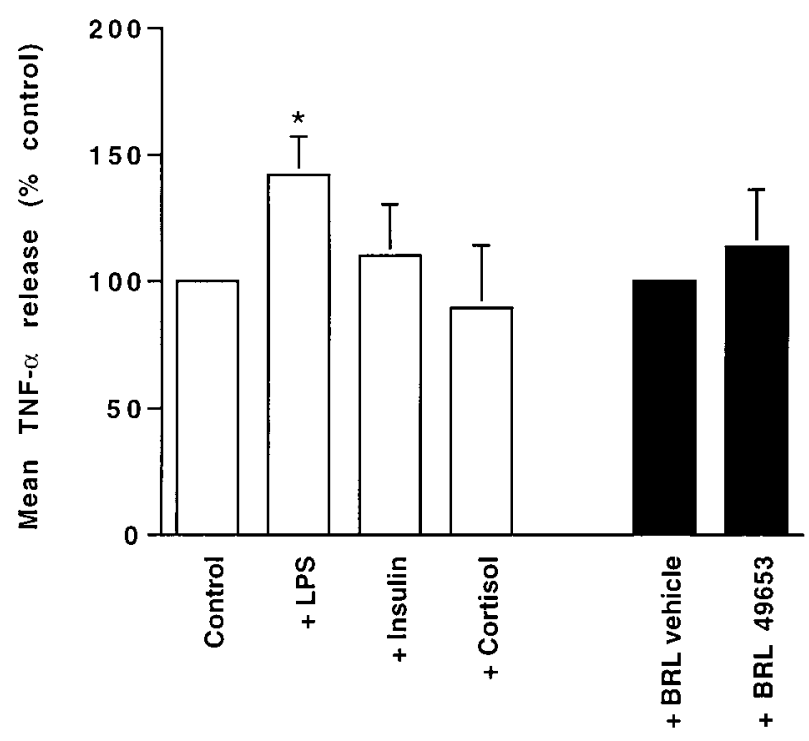

Figure 2 TNF- $\alpha$ release into the incubation medium from isolated human adipocytes after a $20-\mathrm{h}$ incubation period in medium alone (Control) or medium containing $50 \mu \mathrm{g} / \mathrm{ml}$ LPS $(n=7), 7 \mu \mathrm{M}$ insulin $(n=3), 1 \mathrm{mg} / \mathrm{ml}$ cortisol $(n=3)$, or $10^{-7} \mathrm{M}$ BRL $49653(n=4)$. In each experiment, samples were incubated in duplicate. Data are expressed as means \pm S.E.M. ${ }^{*} P=0 \cdot 0469$ compared with Control.

(Fig. 4). Under identical conditions, exposure of human monocyte-macrophages to LPS resulted in a 50 -fold increase in TNF- $\alpha$ release relative to unstimulated controls $(P=<0 \cdot 0001$ data not shown). 


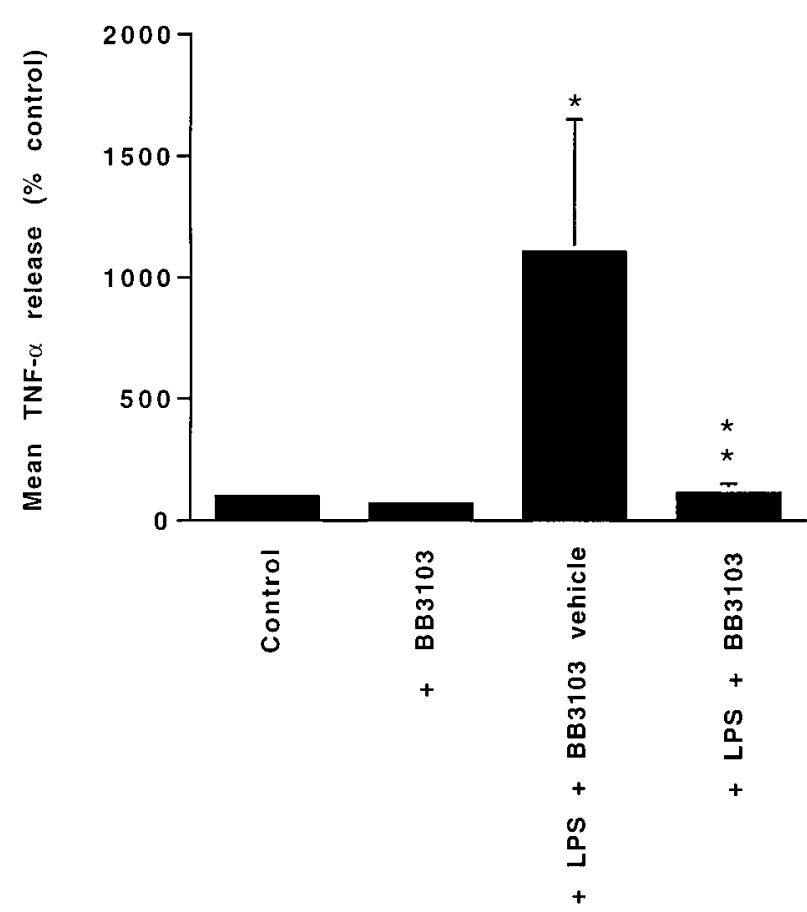

Figure 3 TNF- $\alpha$ release from human adipose tissue after a 20-h incubation in medium alone (Control), medium plus BB3103 $(10 \mu \mathrm{M})$, medium plus LPS $(50 \mu \mathrm{g} / \mathrm{ml})$ plus BB3103 vehicle, or medium containing LPS $(50 \mu \mathrm{g} / \mathrm{ml})$ plus $10 \mu \mathrm{M}$ BB3103 $(n=10)$. In each experiment, samples were incubated in duplicate. Data are expressed as means \pm S.E.M. ${ }^{*} P=0 \cdot 0078$, LPS + BB3 103 vehicle compared with Control; ${ }^{*} P=0 \cdot 002$, LPS $+B B 3103$ vehicle compared with LPS+BB3103.

Previous reports on the study of LPS induction of TNF- $\alpha$ protein production in monocytes and macrophages have shown that this is mediated by CD14, a cell-surface receptor for LPS. CD14 mRNA was detected by RTPCR in isolated adipocytes, preadipocytes and monocytes (Fig. 5).

\section{Discussion}

Although a large body of research on TNF- $\alpha$ action in metabolically important tissue such as muscle and fat has recently emerged, little information has been forthcoming on the regulation of TNF- $\alpha$ release from adipose tissue, and even less on TNF- $\alpha$ release from human adipose tissue. In this study, we have demonstrated that TNF- $\alpha$ release from human adipose tissue is responsive to LPS but not to insulin, cortisol or a thiazolidinedione. LPS also stimulated TNF- $\alpha$ release from isolated adipocytes, albeit less robustly than in whole adipose tissue. The LPSstimulated release of TNF- $\alpha$ was prevented by an inhibitor of the metalloproteinase responsible for the cleavage of the membrane-bound form of TNF. Finally, adipocytes were

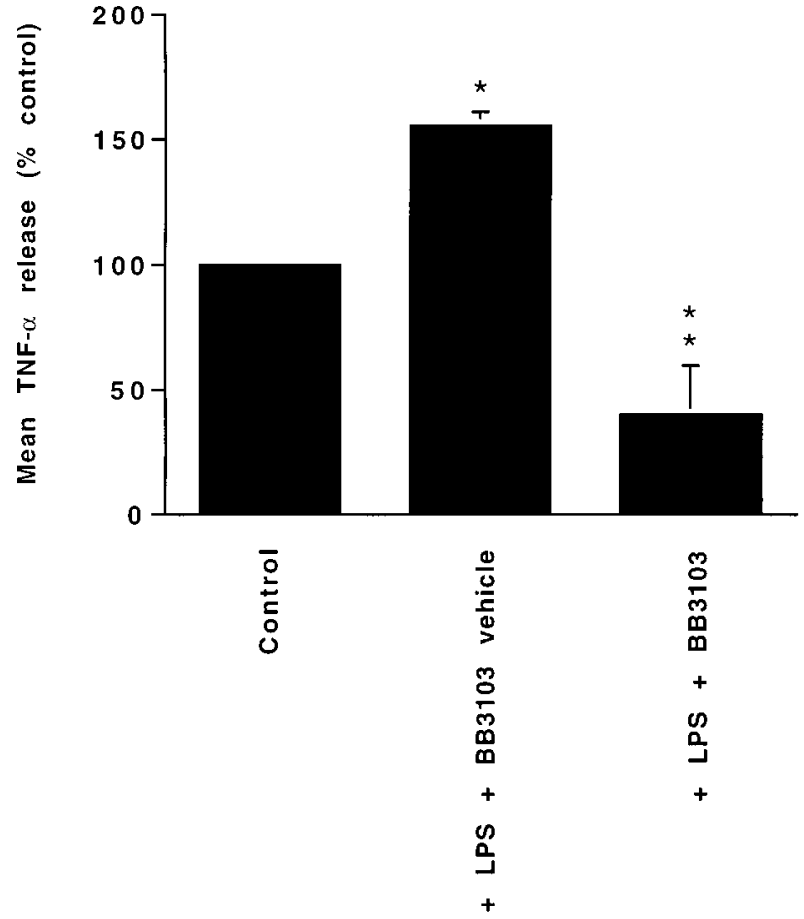

Figure 4 TNF- $\alpha$ release from isolated human adipocytes after a 20-h incubation in medium alone (Control), medium plus LPS $(50 \mu \mathrm{g} / \mathrm{ml})$ plus BB3103 vehicle, or medium containing LPS $(50 \mu \mathrm{g} / \mathrm{ml})$ plus $10 \mu \mathrm{M}$ BB3103 $(n=2)$. In each experiment, samples were incubated in duplicate. Data are expressed as means \pm S.E.M. ${ }^{*} P=0 \cdot 0497$, LPS $+B B 3103$ vehicle compared with Control; ${ }^{* *} P=0 \cdot 03, \mathrm{LPS}+\mathrm{BB} 3103$ vehicle compared with LPS+BB3103.

found to express mRNA encoding CD14, a known receptor for LPS.

As in unstimulated monocytes and macrophages (Crawford et al. 1997), TNF- $\alpha$ release from human adipose tissue and isolated adipocytes under control conditions occurred at low levels. This is consistent with our previously published data concerning TNF- $\alpha$ mRNA expression which indicated that this gene is expressed at very low abundance in human adipocytes (Montague et al. 1998). Interestingly, we were unable to demonstrate any correlation between adipose tissue TNF- $\alpha$ release and the BMI of the subjects studied. This is in contrast to previous studies which demonstrated a $2 \cdot 5$-fold increase in fat tissue TNF- $\alpha$ expression in obese $\left(B M I=39.9 \pm 1.4 \mathrm{~kg} / \mathrm{m}^{2}\right)$ compared with lean $\left(\mathrm{BMI}=21 \cdot 4 \pm 0 \cdot 3 \mathrm{~kg} / \mathrm{m}^{2}\right)$ individuals (Hotamisiligil et al. 1995). The narrow range of BMIs in the present study $\left(20-30 \mathrm{~kg} / \mathrm{m}^{2}\right)$ would not have allowed us to detect an effect of marked obesity. This is consistent with our previously published data concerning TNF- $\alpha$ mRNA expression in adipocytes from a study population with a similar range of BMI values (Montague et al. 1998).

Circulating TNF- $\alpha$ protein concentrations have been reported to correlate with hyperinsulinaemia in humans 


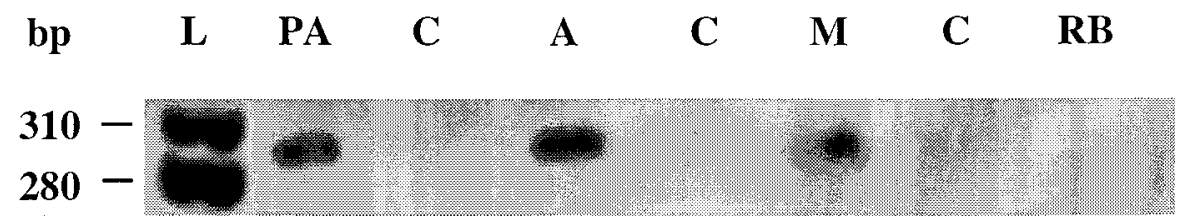

Figure 5 Detection of CD14 mRNA by RT-PCR in isolated adipocytes (A), monocytes (M) and preadipocytes (PA). C, RT-PCR reactions in which reverse transcriptase enzyme was omitted; $L$, $1 \mathrm{~kb}$ ladder; RB, RT-PCR amplification mixture without template as a negative control.

(Hotamisligil et al. 1995). In addition, insulin has been reported to have a stimulatory effect on TNF- $\alpha$ release from monocyte and macrophages (Gepner-Atlan et al. 1996, Hahn \& Filkins 1993). In these studies, however, insulin did not have any significant effect on release of TNF- $\alpha$ protein from either adipose tissue or isolated adipocytes. Cortisol has previously been shown to markedly suppress the endotoxin-induced increase in TNF- $\alpha$ protein production in human macrophages (Beutler et al. 1986). No significant suppression of adipocyte TNF- $\alpha$ by cortisol was seen in this study, although there was a trend towards a reduction. The low basal levels of TNF- $\alpha$ release may have made an inhibitory effect difficult to detect, and future studies should consider the effects of cortisol on LPS-induced secretion. Thiazolidinedione compounds are agonists at the PPAR $\gamma$ receptor (Berger et al. 1996), a nuclear hormone receptor highly expressed in fat (Chawla et al. 1994). They act as insulin sensitisers (Saltiel \& Olefsky 1996) and, in obese rodents treated in vivo have been demonstrated to reduce adipocyte TNF- $\alpha$ expression (Peraldi et al. 1997). In contrast, no effects of the thiazolidinedione, BRL 49653, on TNF- $\alpha$ release from fat tissue were seen in the present study. This apparent discrepancy may relate to species differences, to in vivo and in vitro differences, or to the fact that only fat from non-obese humans was studied.

LPS is a cell-wall component of Gram-negative bacteria that powerfully stimulates TNF- $\alpha$ protein production in monocytes and macrophages (Beutler et al. 1986). In this study, we have demonstrated that LPS also stimulates TNF- $\alpha$ release from human adipose tissue and from isolated human adipocytes. The greater stimulation of TNF- $\alpha$ from whole adipose tissue than from isolated adipocytes may suggest that cells other than adipocytes are responsible for most of the LPS response. However, precise quantitative comparisons are difficult, as the isolated adipocytes have inevitably undergone an isolation procedure that may impair their subsequent responsiveness in vitro. In this regard, Hotamisligil et al. (1993) have reported that the majority of TNF- $\alpha$ expression in fat tissue is in adipocytes, with a minor contribution from the stromovascular fraction.

We have shown that the stimulatory effect of LPS on TNF- $\alpha$ release can be blocked by BB3103, a matrix metalloproteinase inhibitor, and that this effect is seen in both whole adipose tissue and isolated adipocytes. These findings suggest that the increase in TNF- $\alpha$ levels seen on exposure to LPS occurs via normal physiological mechanisms and is unlikely to represent a non-specific lytic effect of LPS. Our results also demonstrate, for the first time, that the release of TNF- $\alpha$ from adipocytes occurs through the same metalloproteinase-mediated mechanism as that seen in more classical TNF- $\alpha$ secreting cells.

The finding that LPS stimulates TNF- $\alpha$ production from human adipocytes suggests a role for adipocyte TNF in host defence. This adds to a growing body of evidence pointing towards a contribution of adipose tissue to innate immunity. Thus adipocytes are a major source of several components of the complement system including factors D (adipsin), B and C3 (Peake et al. 1997). Levine et al. (1998) have recently shown that adipocytes produce macrophage colony-stimulating factor, a proliferative stimulus for macrophages, and that this is upregulated in growing adipose tissue, as seen in 'creeping fat' that surrounds inflammatory intestinal lesions such as in Crohn's disease. Adipose tissue is also known to be a source of interleukin-6 (Fried et al. 1998), a pleiotropic cytokine that has a systemic role in infections and inflammatory disorders as part of the acute phase response. Finally, leptin, a major secretory product of adipocytes, has important effects on lymphocyte function (Lord et al. 1998). In addition, Gainsford and co-workers (1996) found that addition of leptin to culture medium enhanced cytokine production and phagocytosis of Leishmania parasites by murine peritoneal macrophages.

Thus our finding that LPS is a significant secretagogue for TNF- $\alpha$ release from human adipose tissue and adipocytes adds to this growing body of evidence for a role of the adipocyte in innate immunity. These findings do not, however, exclude additional roles for adipocyte TNF- $\alpha$ in the control of other aspects of fat cell biology, such as differentiation, apoptosis and lipid metabolism.

\section{Acknowledgements}

This study was supported by the British Diabetic Association and the Wellcome Trust. J P is a Wellcome Trust International Travelling Fellow. The authors would like to thank Professor Ken Siddle for helpful discussions. The authors would also like to acknowledge the support of Dominic Corkill from British Biotechnology Limited. The assistance of members of the departments of Surgery and 
Obstetrics and Gynaecology of Addenbrooke's Hospital and the University of Cambridge, in particular Peter Friend, Neville Jamieson, John Williamson and Andrew Prentice, is greatly appreciated.

\section{References}

Berger J, Bailey P, Biswas C, Cullinan CA, Doebber TW, Hayes NS, Saperstein R, Smith RG \& Leibowitz MD 1996 Thiazolidinediones produce a conformational change in peroxisomal proliferatoractivated receptor $\gamma$ : binding and activation correlate with antidiabetic actions in $d b / d b$ mice. Endocrinology 137 4189-4195.

Beutler B, Krochin N, Milsark I, Luedke C \& Cerami A 1986 Control of cachectin (tumor necrosis factor) synthesis: mechanisms of endotoxin resistance. Science 232 977-979.

Chawla A, Schwarz E, Dimaculangan D \& Lazar M 1994 Peroxisome proliferator-activated receptor (PPAR) gamma: adiposepredominant expression and induction early in adipocyte differentiation. Endocrinology 135 798-800.

Crawford E, Ensor J, Kalvakolanu I \& Hadsay J 1997 The role of 3' poly (A) tail metabolism in tumor necrosis factor-alpha regulation. Journal of Biological Chemistry 272 21120-21127.

Feinstein R, Kanety H, Papa M, Lunenfeld B \& Karasik A 1993 Tumor necrosis factor-alpha suppresses insulin-induced tyrosine phosphorylation of insulin-receptor and its substrates. Journal of Biological Chemistry 268 26055-26058.

Fried S \& Zechner R 1989 Cachectin tumor necrosis factor decreases human adipose-tissue lipoprotein-lipase messenger-RNA levels, synthesis, and activity. Journal of Lipid Research 30 1917-1923.

Fried S, Bunkin D \& Greenberg A 1998 Omental and subcutaneous adipose tissues of obese subjects release interleukin-6: depot difference and regulation by glucocorticoid. Journal of Clinical Endocrinology and Metabolism 83 847-850.

Gainsford T, Willson T, Metcali D, Handman E, McFarlane C, Ng A, Nicola NA, Alexander WS \& Hilton DJ 1996 Leptin can induce proliferation, differentiation, and functional activation of hemopoietic cells. Proceedings of the National Academy of Sciences of the USA 93 14564-14568.

Gearing A, Beckett P, Christodoulou M, Churchill M, Clements J, Davidson AH, Drummond AH, Galloway WA, Gilbert R, Gordon JL, Leber TM, Mangan M, Miller K, Nayee P, Owen K, Patel S, Thomas W, Wells G, Wood LM \& Woolley K 1994 Processing of tumor necrosis factor- $\alpha$ precursor by metalloproteinases. Nature $\mathbf{3 7 0}$ $555-557$.

Gepner-Atlan C, Bongrand P, Farnarier C, Xerri L, Choux R, Gauthier J-F, Brue T, Vague P, Grob J-J \& Vialettes B 1996 Insulin-induced lipoatrophy in type I diabetes. Diabetes Care 19 1283-1285.

Hahn E \& Filkins J 1993 Insulin restores plasma tumor-necrosis-factor (TNF) in the dexamethasone protected endotoxic rat. FASEB Journal 7 A420.

Hauner H, Petruschke T, Russ M, Rohrig K \& Eckel J 1995 Effects of tumor necrosis factor-alpha (TNF-alpha) on glucose transport and lipid metabolism in newly-differentiated fat cells in culture. Diabetologia 38 764-771.
Hotamisligil G, Shargill N \& Speigelman B 1993 Adipose expression of tumor necrosis factor- $\alpha$ : direct role in obesity-linked insulin resistance. Science 259 87-91.

Hotamisligil G, Arner P, Caro J, Atkinson R \& Spiegelman B 1995 Increased adipose tissue expression of tumor necrosis factor- $\alpha$ in human obesity and insulin resistance. Journal of Clinical Investigation 95 2409-2415.

Kern P, Saghizadeh M, Ong J, Bosch R, Deem R \& Simsolo R 1995 The expression of tumor necrosis factor in human adipose tissue. Journal of Clinical Investigation 95 2111-2119.

Levine J, Jensen M, Eberhardt N \& O'Brien T 1998 Adipocyte macrophage colony-stimulating factor is a mediator of adipose tissue growth. Journal of Clinical Investigation 101 1557-1564.

Lord G, Matarese G, Howard J, Baker R, Bloom R \& Lechler R 1998 Leptin modulates the T-cell immune response and reverses starvation-induced immunosuppression. Nature 394 897-901.

Mijatovic T, Kruys V, Caput D, Defrance P \& Huez G 1997 Interleukin-4 and -13 inhibit tumor necrosis factor alpha mRNA translational activation in lipopolysaccaride-induced mouse macrophages. Journal of Biological Chemistry 22 14394-14398.

Montague C, Prins J, Sanders L, Zhang JL, Sewter CP, Digby J, Byrne CD \& O'Rahilly S 1998 Depot-related gene expression in human subcutaneous and omental adipocytes. Diabetes $\mathbf{4 7}$ 1384-1391.

Peake P, O'Grady S, Pussell B \& Charlesworth J 1997 Detection and quantification of the control proteins of the alternative pathway of the complement in 3T3-L1 adipocytes. European Journal of Clinical Investigation 27 922-927.

Peraldi P, Xu M \& Spiegelman B 1997 Thiazolidinediones block tumor necrosis factor- $\alpha$-induced inhibition of insulin signaling. Journal of Clinical Investigation 100 1863-1869.

Prins J, Niesler C, Winterford C, Bright NA, Siddle K, O’Rahilly S, Walker NI \& Cameron DP 1997 Tumor necrosis factor- $\alpha$ induces apoptosis of human adipose cells. Diabetes 46 1939-1944.

Saltiel A \& Olefsky J 1996 Thiazolidinediones in the treatment of insulin resistance and type II diabetes. Diabetes 45 1661-1669.

Stephens J \& Pekala P 1991 Transcriptional repression of the GLUT4 and C/EBP genes in 3T3-L1 adipocytes by tumor necrosis factor-alpha. Journal of Biological Chemistry 266 21839-21845.

Sumida M, Shiosaka T, Nagar A, Isshikimasuda M, Okuda H \& Hamada M 1997 Suppresive effect of tumor necrosis factor-alpha on adipogenic cell differentiation and on gene expression of hormone-sensitive lipase. Journal of Clinical Biochemistry and Nutrition $221-11$.

Waage A \& Bakke O 1988 Glucocorticoids suppress the production of tumor necrosis factor by lipopolysaccaride-stimulated human monocytes. Immunology 63 299-302.

Zhang B, Berger J, Hu E, Szalkowski D, White-Carrington S, Spiegelman BM \& Moller DE 1996 Negative regulation of peroxisome proliferator-activated receptor- $\gamma$ gene expression contributes to the anti-adipogenic effects of tumor necrosis factor- $\alpha$. Molecular Endrocrinology 10 1457-1466.

Received 29 December 1998

Revised manuscript received 28 April 1999

Accepted 5 May 1999 